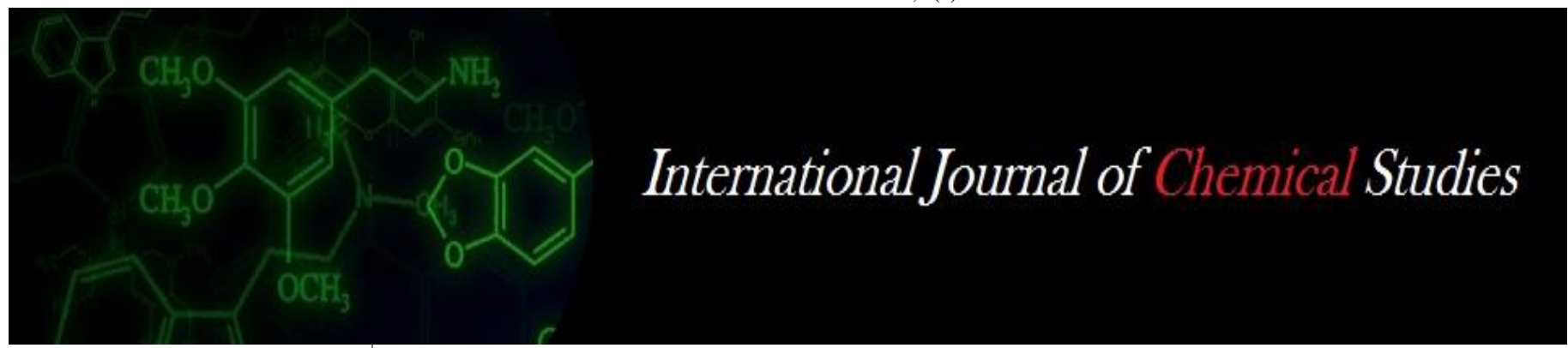

P-ISSN: 2349-8528

E-ISSN: 2321-4902

www.chemijournal.com

IJCS 2020; 8(4): 3196-3200

(C) 2020 IJCS

Received: 27-05-2020

Accepted: 29-06-2020

\section{Pardeep Kaur}

Department of Agriculture, Mata

Gujri College, Fatehgarh Sahib,

Punjab, India

\section{Hardeep Singh}

Department of Agriculture, Mata Gujri College, Fatehgarh Sahib,

Punjab, India

\section{Rajneet Kaur}

Department of Agriculture, Mata Gujri College, Fatehgarh Sahib,

Punjab, India
Corresponding Author:

Pardeep Kaur

Department of Agriculture, Mata

Gujri College, Fatehgarh Sahib,

Punjab, India

\title{
Effect of integrated nutrient management on yield and quality of cauliflower (Brassica oleracea var. botrytis $\mathbf{L}$.) and soil nutrient status
}

\section{Pardeep Kaur, Hardeep Singh and Rajneet Kaur}

DOI: $\underline{\text { htps://doi.org/10.22271/chemi.2020.v8.i4am.10144 }}$

\section{Abstract}

The present investigation 'Effect of integrated nutrient management on yield and quality of cauliflower (Brassica oleracea var. botrytis L.) and soil nutrient status was undertaken at Experimental farm of Department of Agriculture, Mata Gujri College, Fatehgarh Sahib, during 2018-19. The experiment was deliberated in Randomized Block Design (R.B.D) with thirteen treatments replicated thrice. The treatment comprises $\mathrm{T}_{1}$ : Control, $\mathrm{T}_{2}: 100 \% \mathrm{RDF}(125: 62.5: 62.5 \mathrm{~kg} / \mathrm{ha}), \mathrm{T}_{3}: 50 \% \mathrm{RDF}+\mathrm{FYM} @$ 10t/ha, T4: 50\% RDF + Vermicompost @ 4t/ha, T5 : 50\% RDF + FYM @ 5t/ha + Vermicompost @ 2t/ha, T6 : 50\% RDF + Azotobacter @ 250g/ha, T7 : 50\% RDF + FYM @ 10t/ha + Azotobacter @ 250g/ha, T8: 50\% RDF + Vermicompost @ 4t/ha + Azotobacter @ 250g/ha, T9: 50\% RDF + FYM @ 5t/ha+Vermicompost @ 2t/ha + Azotobacter @ 250g/ha, T10: 50\% RDF + Azospirillum @ 250g/ha, $\mathrm{T}_{11}$ : 50\% RDF + FYM @ 10t/ha + Azospirillum @ 250g/ha, T12: 50\% RDF + Vermicompost @ 4t/ha + Azospirillum @ 250g/ha, T13: 50\% RDF+Vermicompost @2t/ha + FYM @ 5t/ha + Azospirillum @ $250 \mathrm{~g} / \mathrm{ha}$. From the studies, it can be inferred that application of $50 \% \mathrm{RDF}+$ Vermicompost @ 2t/ha + FYM @ 5t/ha + Azospirillum @ 250g/ha was found to be the most effective treatment for getting enhanced yield and quality in cauliflower.

Keywords: Azospirillum, Azotobacter, cauliflower and vermicompost

\section{Introduction}

Recent developments in agriculture have contributed a lot towards improvement in vegetable production throughout the world. India can claim to grow largest number of vegetables crops as compared to other countries in the world as many as 61 annual and 4 perennial vegetable crops are commercially cultivated, Ram (2005) ${ }^{[16]}$. Cauliflower (Brassica oleracea var. botrytis L.) is one of the most important vegetable crops belonging to the family Brassicaceae. It is being grown round the year for its white and tender curd. It is widely cultivated all over India and abroad for its special nutritive values, high productivity and wider adaptability under different ecological conditions (Roy, 1981) ${ }^{[17]}$. The technique of organic farming plays a role in cultivation of high value vegetable crops (Khan et al. 2008) ${ }^{[8]}$. The application of high input technologies, such as chemical fertilizers, pesticides, herbicides improve the production but there is growing concern over the adverse effects of the use of chemicals on human health, soil productivity and environment quality, Sharma et al. 2012. Bio-fertilizers improve the quantitative and qualitative features of many plants (Yousefi et al. 2011) ${ }^{[25]}$. The integrated management of nutrient, in its proper prospective, may be adopted to support enhanced productivity and quality of vegetables (Kiran et al.2010) ${ }^{[9]}$. The integrated nutrient management having chemical fertilizers along with organic sources of nutrients is an effective method for economization of production cost as well as maintenance soil fertility (Kumar et al. 2011) ${ }^{[11]}$. Azospirillum is an effective micro-aerophilic nitrogen fixer. It colonizes the root moss and fixes nitrogen in loose association with plants. Azospirillum fix nitrogen from 10-40 $\mathrm{kg} / \mathrm{ha} /$ season in many vegetable crops thereby $25-30 \%$ nitrogenous fertilizers, whereas Azotobacter saves addition to nitrogenous fertilizer by $10-20 \%$. Its inoculation helps the plants in better vegetative growth due to production of growth hormones such as auxins, gibberellins and cytokinins. 


\section{Material and methods}

The field experiment was set out at Experimental farm, Department of Agriculture, Mata Gujri College, Fatehgarh Sahib during 2018-19. Cauliflower variety "Pusa Snowball K1 " was sown in field on October $1^{\text {st }}$ and nursery bed of $1.0 \mathrm{~m}$ wide and $15 \mathrm{~cm}$ high from ground level was prepared for raised seedlings. Four weeks old seedlings were transplanted at spacing $45 \times 45 \mathrm{~cm}$ on $1^{\text {st }}$ November 2018 after giving seedling treatment with bio-fertilizer. In INM Plots, half dose of $\mathrm{N}$ and full amount of $\mathrm{P}$ and $\mathrm{K}$ were applied as basal during planting, and rest of $\mathrm{N}$ dose was top dressed in two splits at 30 and 60 days after transplanting (DAT). The thirteen treatment, were evaluated in Randomized Block Design with three replications. The observations were recorded on randomly selected plants i.e. curd length $(\mathrm{cm})$, curd diameter $(\mathrm{cm})$, average curd weight $(\mathrm{g})$, curd yield per plot $(\mathrm{kg})$, curd yield per ha (t/ha), biological yield $(\mathrm{kg})$, harvest index $(\%)$, shelf life (days), ascorbic acid (mg/100g), TSS ( ${ }^{\circ}$ Brix), dry matter of curd (\%), chlorophyll (a) content of leaves, chlorophyll(b) content of leaves, total chlorophyll content of leaves, titratable acidity $(\%)$, available NPK in the soil before start of experiment and after final harvest, organic carbon $(\%), \mathrm{pH}$, EC and economic parameters (Total cost of cultivation, net return, gross return and $\mathrm{B}: \mathrm{C}$ ratio).

The experimental data of all parameters was subjected to statistical analysis for proper interpretation. The statistical analysis of data in respect of the growth and yield components was done according to the standard procedure given for randomized block design by Panse and Sukhatme (1967).

Table 1: Treatment details and their symbols

\begin{tabular}{|c|c|}
\hline Treatment details & Symbol \\
\hline Control & $\mathrm{T}_{1}$ \\
\hline 100\% RDF(125:62.5:62.5) & $\mathrm{T}_{2}$ \\
\hline 50\%RDF+FYM (10t/ha) & $\mathrm{T}_{3}$ \\
\hline 50\%RDF+Vermicompost(4t/ha) & $\mathrm{T}_{4}$ \\
\hline 50\%RDF+FYM(5t/ha)+Vermicompost(2t/ha) & $\mathrm{T}_{5}$ \\
\hline 50\%RDF+Azotobacter(250g/ha) & $\mathrm{T}_{6}$ \\
\hline 50\%RDF+FYM(10t/ha)+Azotobacter(250g/ha) & $\mathrm{T}_{7}$ \\
\hline 50\%RDF+ Vermicompost (4t/ha)+Azotobacter(250g/ha) & $\mathrm{T}_{8}$ \\
\hline 50\%RDF+FYM(5t/ha)+Vermicompost (2t/ha)+Azotobacter & $\mathrm{T}_{9}$ \\
\hline (250g/ha) & $\mathrm{T}_{10}$ \\
\hline 50\%RDF+Azospirillum(250g/ha) & $\mathrm{T}_{11}$ \\
\hline 50\%RDF+Vermicompost(4t/ha)+Azospirillum(250g/ha) & $\mathrm{T}_{12}$ \\
\hline 50\%RDF+ Vermicompost & $\mathrm{T}_{13}$ \\
\hline (2t/ha)+FYM(5t/ha)+Azospirillum (250g/ha) & \\
\hline
\end{tabular}

\section{Results and Discussion}

\section{Effect on yield attributes, crop yield}

Yield and yield related attributes of cauliflower exhibited as beneficial response to all treatment under the study. Treatment $\mathrm{T}_{13^{-}}$50\% RDF + FYM @ 5t/ha + Vermicompost @ 2t/ha + Azospirillum @ 250g/ha registered significantly higher value for curd length $(13.50 \mathrm{~cm})$ and curd polar and equatorial diameter i.e. 16.00 and $18.33 \mathrm{~cm}$. this might be due to that Azospirillum has definite role in cell division, cell enlargement, cell elongation and physiological activities. These physiological activities give beneficial response on uptake of water and nutrients development of cambial growth, respiration, co-enzyme activity, utilization of Adenosine

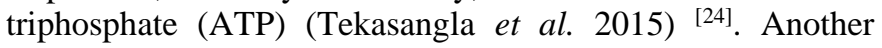
reason behind this is due to an increase nitrogen content by bio-fertilizers and which stimulates the photosynthetic activity by the elevation of the content of stromal and thylakoid proteins in leaves (Jha et al. 2017) ${ }^{\text {[7] }}$. It is apparent from the data that the fresh weight of curd was found maximum $(890.00 \mathrm{~g})$ from $\mathrm{T}_{13}$. The higher weight of cauliflower curd might be due to better root proliferation and rhizosphere development, uptake of nutrients and water and maximum leaf area development that ultimately leads to higher rate of photosynthesis activity (Chaudhary et al. 2015) ${ }^{[3]}$. The curd yield was recorded significantly higher $\left(32.04 \mathrm{t} / \mathrm{ha}\right.$ ) from $\mathrm{T}_{13}$ treatment having 50\% RDF + FYM + Vermicompost + Azospirillum which was superior over rest of the treatments. It also might be due to application of NPK in conjuction with biofertilizers and organic manure might have favored the effective utilization of nutrient availability in the soil, which ultimately increased auxin activity, growth and activity of microbial saprophytes, which ultimately influenced the yield per ha. These results are in accordance with the findings of Singh et al. $2002^{[20]}$ in cabbage, Manivanan and Singh (2004) [12] in broccoli. The present trend of increase in harvesting index is in close conformity with the findings of Manna et al. $2005^{[13]}$, Abraham et al. (2008) ${ }^{[1]}$ in groundnut. Minimum yield was recorded in control treatment.

\section{Effect on quality of cauliflower and Economics}

Quality related attributes were significantly influences by various treatments. Treatments $\mathrm{T}_{13}$ i.e. $50 \% \mathrm{RDF}+\mathrm{FYM}$ $(5 \mathrm{t} / \mathrm{ha})+$ Vermicompost $(2 \mathrm{t} / \mathrm{ha})+$ Azospirillum $(250 \mathrm{~g} / \mathrm{ha})$ resulted in significantly higher shelf life (10.07days), ascorbic acid content (77.03 mg $\left.100 \mathrm{~g} \mathrm{~g}^{-1}\right)$, TSS-total soluble solids (7.70 ${ }^{\circ}$ Brix), dry matter of curd $(13.30 \%)$, minimum TA- titratable acidity $(0.25 \%)$, maximum chlorophyll content $(0.59 \mathrm{mg} 100$ $\left.\mathrm{g}^{-1}\right)$, chlorophyll(b) content $\left(0.35 \mathrm{mg} 100 \mathrm{~g}^{-1}\right)$ and total chlorophyll content of leaves $\left(1.90 \mathrm{mg} 100 \mathrm{~g}^{-1}\right)$ as compare to rest of treatments. The higher shelf life in this treatment due to inorganic fertilizers in combination with higher amount of organic manure and biofertilizers results into slower rate of respiration and transpiration which might have prevented the moisture loss from the curd surface and resulted in delayed in loosening of curd. (Chatterjee et al. 2012). The increase in ascorbic acid content in cauliflower might be due to increase in microbial activity of soil which might have added growth regulators, vitamins and hormones to the plants (Devi et al. 2017) ${ }^{[5]}$. High TSS might be due to increased photosynthetic activity and other mineral resulted improved levels of carbohydrates of cauliflower curd through the way of enzymatic activity that stimulated by plant growth substances produced by application of Azospirillum and other nutrients (Singh et al. 2018) ${ }^{[21]}$. The increased dry matter percent in curd might be due to the fact that nitrogen is the major constituent of plant protein, amino acid and carbohydrate, as a result of increased uptake of nitrogen might have increased dry matter per cent (Kumar et al. 2002) ${ }^{[10]}$. However, increased level of organic manures gradually improved the chlorophyll content of leaves and addition of bio-fertilizers had further increased the values (Chatterjee et al. (2012). The reduction in titratable acidity may be attributed to conversion of organic acids and phytosynthates into sugar during fruit ripening by applying bio-fertilizers (Ahmadi et al. 2017) ${ }^{[2]}$.

Examination of the data revealed that maximum net returns per hectare (Rs.149637.2) was obtained in treatment $\mathrm{T}_{13}(50 \%$ $\mathrm{RDF}+\mathrm{FYM} @ 5 \mathrm{t} / \mathrm{ha}+$ Vermicompost @ 2t/ha + Azospirillum @ 250g/ha)with the benefit: cost ratio of 2.00:1. Whereas, minimum income was obtained in control. The minimum ratio 1.00:1 was obtained in $\mathrm{T}_{3}: 50 \% \mathrm{RDF}+\mathrm{FYM}$ @ 10t/ha. The reason for increased profit and benefit: cost ratio is due to maximum marketable yield which was due to healthy and better fruit size and which results in higher B: C 
ratio (Shree et al. 2014) ${ }^{[18]}$. The benefit cost ratio was also calculated by Singh and Singh (2005) ${ }^{[22]}$ and economics was also calculated by Singh et al. (2009) ${ }^{[19]}$.

\section{Soil properties}

Addition of RDF, Farm yard manure, vermicompost and biofertilizers had a positive effect on soil $\mathrm{pH}$, soil electrical conductivity, organic carbon, available nitrogen, phosphorus and potassium. The value of the minimum (7.87) $\mathrm{pH}, \mathrm{EC}$ $(0.20)$ value was recorded in treatment $\mathrm{T}_{13}(50 \% \mathrm{RDF}+\mathrm{FYM}$ (5t/ha) + Vermicompost (2t/ha) + Azospirillum (250g/ha). The decline in soil $\mathrm{pH}$ with the application of biofertilizers might be due to the production of organic matter as resulted produced organic acids by the microbial activity. The electrical conductivity slightly increased in the plots receiving only chemical fertilizers. The possible reason for this might be due to direct addition of organic matter through decomposition of organic manure and recycling of organic materials (Shree et al. 2014) ${ }^{[18]}$. Maximum value of organic carbon $(0.78 \%)$, available nitrogen $(312.3 \mathrm{~kg} / \mathrm{ha})$, phosphorus $(19.77 \mathrm{~kg}),(173.07 \mathrm{~kg})$ available potassium was observed in $\mathrm{T}_{13}(50 \% \mathrm{RDF}+\mathrm{FYM}(5 \mathrm{t} / \mathrm{ha})+$ Vermicompost $(2 \mathrm{t} / \mathrm{ha})+$
Azospirillum (250g/ha). The net increase in organic carbon was much higher with organic manures in combination with biofertlizers and fertilizers over $100 \%$ NPK alone. This might be due to increased microbial activities in the root zone which decomposed organic manures and also fixed unavailable form of mineral nutrients into available forms in soil thereby substantiated crop requirements and improved organic carbon level (Tekasangla et al. 2015) ${ }^{[24]}$. Available nitrogen can be increased by addition of nitrogeneous fertilizers and biofertilizers to the manures thereby, reducing the $\mathrm{C}: \mathrm{N}$ ratio. The result obtained on the beneficial effect of inorganic fertilizers, organic manure and biofertilizers were in collaboration with the findings of Stevenson (1982) [23], Ganesh et al. (2011) and (Pawar et al. 2018) in cauliflower. The application of bio-fertilizers could be a higher number of $\mathrm{N}, \mathrm{P}$ and $\mathrm{K}$ content in it due to bacteria present under inoculated conditions. The result obtained collaborated with the reports of Ganesh et al. (2011) [6] in cauliflower. Chaudhary et al. (2005) ${ }^{[4]}$ reported that the incorporation of biofertilizers and FYM with inorganic fertilizers significantly improved the potash status of soil in tomato.

Table 2: Effect of integrated nutrient management on yield and yield contributing traits

\begin{tabular}{|c|c|c|c|c|c|c|c|}
\hline Treatment & $\begin{array}{c}\text { Curd } \\
\text { length } \\
(\mathbf{c m})\end{array}$ & $\begin{array}{c}\text { Curd polar } \\
\text { diameter } \\
(\mathrm{cm})\end{array}$ & $\begin{array}{c}\text { Curd equatorial } \\
\text { diameter } \\
(\mathrm{cm})\end{array}$ & $\begin{array}{c}\text { Average curd weight } \\
\text { (g) }\end{array}$ & $\begin{array}{c}\text { Yield } \\
\left(t_{\text {hat }}^{-1}\right)\end{array}$ & $\begin{array}{l}\text { Biological yield } \\
\quad\left(\mathrm{kg} \mathrm{ha}^{-1}\right)\end{array}$ & $\begin{array}{c}\text { Harvest } \\
\text { index } \\
(\%)\end{array}$ \\
\hline $\mathrm{T}_{1}$ & 9.00 & 11.53 & 15.73 & 520.00 & 18.72 & 0.81 & 57.12 \\
\hline $\mathrm{T}_{2}$ & 13.10 & 15.27 & 18.00 & 796.70 & 28.68 & 1.00 & 71.93 \\
\hline $\mathrm{T}_{3}$ & 9.17 & 11.60 & 16.63 & 590.33 & 21.25 & 0.83 & 59.87 \\
\hline $\mathrm{T}_{4}$ & 9.33 & 12.27 & 16.77 & 605.00 & 21.78 & 0.87 & 58.70 \\
\hline $\mathrm{T}_{5}$ & 12.20 & 14.47 & 17.27 & 743.33 & 26.76 & 0.99 & 68.37 \\
\hline $\mathrm{T}_{6}$ & 9.83 & 11.63 & 16.17 & 543.33 & 19.56 & 0.84 & 57.45 \\
\hline $\mathrm{T}_{7}$ & 10.10 & 12.73 & 16.87 & 620.00 & 22.32 & 0.84 & 66.98 \\
\hline $\mathrm{T}_{8}$ & 10.40 & 13.57 & 17.10 & 640.00 & 23.04 & 0.89 & 65.59 \\
\hline $\mathrm{T}_{9}$ & 13.30 & 15.40 & 18.20 & 810.00 & 29.16 & 1.03 & 73.49 \\
\hline $\mathrm{T}_{10}$ & 10.00 & 11.77 & 16.37 & 547.00 & 19.69 & 0.85 & 57.37 \\
\hline $\mathrm{T}_{11}$ & 9.53 & 13.20 & 17.03 & 630.00 & 22.68 & 0.87 & 65.10 \\
\hline $\mathrm{T}_{12}$ & 11.37 & 13.63 & 17.20 & 690.00 & 24.84 & 0.88 & 67.67 \\
\hline $\mathrm{T}_{13}$ & 13.50 & 16.00 & 18.33 & 890.00 & 32.04 & 1.09 & 75.11 \\
\hline $\mathrm{SE}(\mathrm{m}) \pm$ & 0.27 & 0.27 & 0.23 & 16.43 & 0.59 & 0.03 & 1.87 \\
\hline $\mathrm{CD}_{0.05}$ & 0.77 & 0.79 & 0.66 & 47.96 & 1.73 & 0.09 & 5.45 \\
\hline
\end{tabular}

Table 3: Effect of integrated nutrient management on quality parameters of cauliflower

\begin{tabular}{|c|c|c|c|c|c|c|c|c|}
\hline Treatment & $\begin{array}{c}\text { Shelf } \\
\text { life } \\
\text { (days) }\end{array}$ & $\begin{array}{c}\text { Ascorbic acid } \\
(\mathrm{mg} / \mathbf{1 0 0 g})\end{array}$ & $\begin{array}{c}\text { TSS } \\
\left({ }^{\circ}\right. \\
\text { Brix }) \\
\end{array}$ & $\begin{array}{c}\text { Dry matter } \\
\text { of curd } \\
(\%)\end{array}$ & \begin{tabular}{|c|} 
Titratable \\
acidity $(\%)$
\end{tabular} & $\begin{array}{c}\text { Chlorophyll (a) content } \\
\text { of leaves }(\mathrm{mg} / 100 \mathrm{~g})\end{array}$ & $\begin{array}{c}\text { Chlorophyll (b) } \\
\text { content of } \\
\text { leaves }(\mathrm{mg} / \mathbf{1 0 0 g})\end{array}$ & $\begin{array}{c}\text { Total chlorophyll } \\
\text { content of } \\
\text { leaves }(\mathrm{mg} / 100 \mathrm{~g})\end{array}$ \\
\hline $\mathrm{T}_{1}$ & 6.70 & 68.50 & 6.10 & 10.00 & 0.54 & 0.41 & 0.20 & 1.08 \\
\hline $\mathrm{T}_{2}$ & 9.48 & 76.24 & 7.47 & 12.77 & 0.30 & 0.51 & 0.30 & 1.76 \\
\hline $\mathrm{T}_{3}$ & 6.73 & 68.60 & 6.17 & 10.07 & 0.47 & 0.44 & 0.22 & 1.35 \\
\hline $\mathrm{T}_{4}$ & 6.77 & 68.83 & 6.23 & 10.93 & 0.34 & 0.43 & 0.21 & 1.40 \\
\hline $\mathrm{T}_{5}$ & 8.80 & 72.70 & 7.07 & 12.45 & 0.33 & 0.48 & 0.27 & 1.64 \\
\hline $\mathrm{T}_{6}$ & 7.47 & 68.53 & 6.40 & 10.10 & 0.48 & 0.46 & 0.22 & 1.39 \\
\hline $\mathrm{T}_{7}$ & 6.80 & 70.23 & 6.25 & 11.00 & 0.44 & 0.46 & 0.23 & 1.40 \\
\hline $\mathrm{T}_{8}$ & 8.10 & 70.33 & 6.70 & 11.05 & 0.35 & 0.47 & 0.25 & 1.56 \\
\hline $\mathrm{T}_{9}$ & 9.53 & 76.37 & 7.60 & 12.83 & 0.26 & 0.53 & 0.32 & 1.77 \\
\hline $\mathrm{T}_{10}$ & 7.50 & 69.20 & 6.37 & 10.20 & 0.43 & 0.45 & 0.23 & 1.41 \\
\hline $\mathrm{T}_{11}$ & 7.57 & 69.47 & 6.30 & 11.03 & 0.33 & 0.47 & 0.24 & 1.63 \\
\hline $\mathrm{T}_{12}$ & 8.17 & 69.67 & 6.57 & 11.79 & 0.34 & 0.48 & 0.28 & 1.53 \\
\hline $\mathrm{T}_{13}$ & 10.07 & 77.03 & 7.70 & 13.30 & 0.25 & 0.59 & 0.35 & 1.9 \\
\hline $\mathrm{SE}(\mathrm{m}) \pm$ & 0.20 & 0.80 & 0.11 & 0.23 & 0.01 & 0.02 & 0.01 & 0.04 \\
\hline $\mathrm{CD}_{0.05}$ & 0.58 & 2.33 & 0.31 & 0.67 & 0.04 & 0.04 & 0.02 & 0.11 \\
\hline
\end{tabular}


Table 4: Effect of INM on economics of cauliflower

\begin{tabular}{|c|c|c|c|c|}
\hline Treatment & Total cost of cultivation $\left(₹ h^{-1}\right)$ & Gross income ( $\left.₹ \mathrm{ha}^{-1}\right)$ & Net return $\left(₹\right.$ ha $\left.^{-1}\right)$ & B: C ratio \\
\hline $\mathbf{T}_{1}$ & 61630.6 & 131040.0 & 69409.4 & 1.13 \\
\hline $\mathbf{T}_{2}$ & 68567.6 & 200768.4 & 132200.8 & 1.93 \\
\hline $\mathbf{T}_{3}$ & 74349.1 & 148764.0 & 74414.9 & 1.00 \\
\hline $\mathbf{T}_{4}$ & 74149.1 & 152460.0 & 78310.9 & 1.06 \\
\hline $\mathbf{T}_{5}$ & 74249.1 & 187320.0 & 113070.9 & 1.52 \\
\hline $\mathbf{T}_{6}$ & 65826.6 & 136920.0 & 71093.4 & 1.08 \\
\hline $\mathbf{T}_{7}$ & 74376.6 & 156240.0 & 81863.4 & 1.10 \\
\hline $\mathbf{T} 8$ & 74526.6 & 161280.0 & 86753.4 & 1.16 \\
\hline $\mathbf{T}_{9}$ & 74626.6 & 204120.0 & 129493.4 & 1.74 \\
\hline $\mathbf{T}_{10}$ & 65842.85 & 137844.0 & 72001.2 & 1.09 \\
\hline $\mathbf{T}_{11}$ & 74392.85 & 158760.0 & 84367.2 & 1.13 \\
\hline $\mathbf{T}_{12}$ & 74542.85 & 173880.0 & 99337.2 & 1.33 \\
\hline $\mathbf{T}_{13}$ & 74642.85 & 224280.0 & 149637.2 & 2.00 \\
\hline
\end{tabular}

\section{Conclusion}

From the findings of present investigation, it can be concluded that integrated approach of $50 \%$ recommended dose of NPK, FYM, Vermicompost, bio-fertilizers performed better with respect to yield and quality contributing traits. On the basis of results summarized above, it can be concluded that application of $50 \% \mathrm{RDF}+\mathrm{FYM} @ 5 \mathrm{t} / \mathrm{ha}+$ Vermicompost@2t/ha +Azospirillum @250g/ha gave best result. It also improved the soil characters like $\mathrm{pH}$ with minimum deterioration of already available nutrient content of soil. Whereas, quality characters (TSS, ascorbic acid, shelf life and chlorophyll content, titratable acidity) performed better under 50\% RDF + FYM @ 5t/ha + Vermicompost @ 2t/ha + Azospirillum @ 250g/ha. The lowest net income overall was in control treatment. Thus it can be said that for obtaining higher cauliflower yield as well as profit from cauliflower application of recommended dose of fertilizer, vermicompost and bio-fertilizer should be applied as optimum nutrition is the key to achieve maximum crop production. Hence, $T_{13}$ can be suggested as a effective nutrient module for getting higher yield and quality with net saving of fertilizers in cauliflower cultivation on sustainable basis.

Application of research: Beneficial to farmers and improve soil health.

\begin{tabular}{lll}
\multicolumn{2}{l}{ Abbreviations } \\
$\mathrm{RDF}$ & $:$ & Recommended dose of fertilizer \\
$\mathrm{Kg}$ & $:$ & Kilogram \\
$\mathrm{G}$ & $:$ & Gram \\
$\%$ & $:$ & Percentage \\
$\mathrm{q} / \mathrm{ha}$ & $:$ & Quintal per Hectare \\
$\mathrm{Sem}$ & $:$ & Standard error mean \\
$\mathrm{CD}$ & $:$ & Critical differences \\
$\mathrm{Cm}$ & $:$ & Centimetre
\end{tabular}

Acknowledgement: The authors are thankful to Department of Agriculture, Mata Gujri College, Fatehgarh Sahib, for the facilities provided during the experiment.

Author Contributions: All author equally contributed

Author statement: All author read, reviewed, agree an approved the final manuscript

Ethical approval: This article does not contain any studies with human participants or animals performed by any of the authors

\section{References}

1. Abraham T, Thenua OVS, Singh SP, Jacob P. Performance of groundnut as influenced by organic and inorganic sources of nutrients and their method of application. Legume Research. 2008; 31:224-26.

2. Ahmadi E, Honnabyraiah MK, Alur AS, Adiga JD, Rao V. Impact of integrated nutrient management on yield and quality parameters of strawberry (Fragaria $\times$ ananassa Duch.) cv. "Sabrina" under polyhouse. International Journal of Current Microbiology and Applied Sciences. 2017; 6(9):3481-3487.

3. Chaudhary MM, Bhanvadia AS, Parmar PN. Effect of integrated nutrient management on growth, yield and yield attributes of Cabbage (Brassica oleracea var. capitata L.). Trends in Bio Sciences. 2015; 8(8):21642168.

4. Choudhary RK, Choudhary DN. Effect of different levels of nitrogen and phosphorous on growth, yield and quality of hybrid cabbage. Haryana Journal of Horticulture Science. 2005; 4(1-2):145-146.

5. Devi S, Choudhary M, Jat PK, Singh SP, Rolaniya MK. Influenced of organic and biofertilizers on yield and quality of cabbage (Brassica oleracea var. capitata). International Journal of Chemical Science. 2017; 5(4):818-820.

6. Ganesh P, Tharamraj K, Kolanjinathan K. Effect of inorganic manure and bio-fertilizers on physical, biological properties and growth of rice by application study. International Journal of Current Life Science 2011; 1(1):11-15.

7. Jha MK, Jha B, Urraiya P, Sahu MR. Effect of organic, inorganic and biofertilizers on growth attributes of cabbage (Brassica oleracea var. capitata). Journal of Pharmacognosy and Phytochemistry. 2017; 6(6):502-504.

8. Khan MS, Shil NC, Noor S. Integrated nutrient management for sustainable yield of major vegetable crops in Bangladesh. Bangladesh Journal of Agriculture and Environment. 2008; 4:81-94.

9. Kiran J, Vyakarana BS, Raikar SD, Ravikumar GH, Deshpande VK. Seed yield and quality of brinjal as influenced by crop nutrition. Indian Journal of Agricultural Research 2010; 44(1):1-7.

10. Kumar M, Rawat TS. Effect of nitrogen and spacing on quality of cabbage (Brassica oleracea L. var. capitata). Agricultural Research Digest. 2002; 22:90-92.

11. Kumar S, Verma MK, Yadav YC. Studies on effect of biofertilizers with chemical fertilizers on growth and yield of cauliflower (Brassica oleracea var. botrytis) cv. 
Pusa Snowball K-1. Annals of Horticulture. 2011; 4(2):202-205.

12. Manivannan MI, Singh JP. Effect of biofertilizers on growth and yield of sprouting broccoli (Brassica oleracea var. italica) under Allahabad agro-climatic conditions. Bioved Journal. 2004; 15(1/2): 33-36.

13. Manna MC, Swarup A, Wanjari RH, Ravankar NH, Mishra B, Saha MN et al. Long term effect of fertilizer and manure application on soil organic carbon storage, soil quality and yield sustainability under sub-humid and semi-arid tropical India. Field Crops Research 2005; 93:264-280.

14. Panse VG, Sukatme. Statistical methods for agricultural workers. ICAR, New Delhi, 1978, 51-55.

15. Pawar R, Barkule S. Study on effect of integrated nutrient management on growth and yield of cauliflower (Brassica oleracea var. botrytis L.). Journal of Applied and Natural Science 2017; 9(1):520-525.

16. Ram HH. Vegetable Breeding principles and practices, Kalyani publishers 2005; (2):3.

17. Roy HK. Effect of nitrogen on curd size and yield of cauliflower. Veg. Sci. 1981; 8(2):75-78.

18. Shree S, Singh VK, Kumar R. Effect of integrated nutrient management on yield and quality of cauliflower (Brassica oleracea L. var. botrytis). An International Quarterly Journal of Life Sciences. 2014; 9(3):10531058.

19. Singh A, Singh T, Singh BN. Influence of integrated nutrient management on growth, yield and economics of cauliflower (Brassica oleracea L. var. botrytis). Vegetable Science 2009; 36(3):340-343.

20. Singh B, Phookan DB, Gautam BP, DK. Effect of nitrogen, phosphorous and potassium on production of broccoli (Brassica oleracea var. italica) cv. $\mathrm{KTS}^{-1}$. Vegetable Science. 2002; 27(1):99-100.

21. Singh RK, Kumar P, Singh SK, Singh SB, Singh RN. Effect of Integrated Nutrient Management on Yield and Economics of Mustard (Brassica juncea L.). International Journal of Current Microbiology and Applied Sciences. 2018; 7:5261-5269.

22. Singh VN, Singh SS. Effect of inorganic and biofertilizers on production of cauliflower (Brassica oleracea L. var. botrytis). Journal of Vegetable Science. 2005; 32(2):146-149.

23. Stevenson FJ. Humus Chemistry, genesis, composition reaction. Wiley-inter science, New York, 1982.

24. Tekasangla, Kanaujia SP, Singh PK. Integrated nutrient management for quality production of cauliflower in acid alfisol of Nagaland. Karnataka Journal of Agricultural Science. 2015; 28(2):244-247.

25. Yousefi AA, Khavazi K, Moezi AA, Rejali F, Nadian H A. Phosphate solubilizing bacteris and Arbuscular mycorrhizal fungi impacts on inorganic phosphorus fractions and wheat growth. World applied Sciences Journal. 2011; 15(9):1310-1318. 